\title{
O inverossímil como parte do cotidiano mágico no universo infantil: uma análise da obra $A$ bolsa amarela, de Lygia Bojunga
}

\author{
The Improbable As Part of the Magical Daily in the Child's Universe: \\ an Analysis of the Book The Yellow Bag, by Lygia Bojunga
}

VAldiREne Rosa DA Silva Melo [guaranimel@yahoo.com.br]
Secretaria de Estado da Educação do Piauí, Brasil

Saulo Cunha de Serpa Brandão [saulo@ufpi.edu.br]

Universidade Federal de Piauí, Brasil / Secretaria Municipal de Educação de Teresina, Brasil

\begin{abstract}
RESUMO
O presente artigo tem como objetivo fazer uma análise sobre a ocorrência de fatos que fogem à convencionalidade da realidade empírica na obra A bolsa amarela, da escritora Lygia Bojunga Nunes, a partir da perspectiva do gênero Maravilhoso. Na citada obra é possível perceber a recorrência de elementos mágicos povoando o ambiente narrativo de maneira natural onde animais e objetos assumem a característica de falar e interagir com a protagonista, misturando o real e a fantasia para compor a narrativa. Nesta perspectiva, será proposta para esta análise uma leitura crítico-interpretativa da presença do inverossímil como um mecanismo questionador dos modelos de comportamento social impostos à sociedade brasileira, em especial à mulher. Na referida obra Lygia aborda os conflitos internos e externos da personagem por meio de amigos secretos, animais antropomorfizados e objetos mágicos para questionar os papéis sociais pré-estabelecidos ou estereotipados, passando a ser o elemento sobrenatural na narrativa uma forma da autora contestar práticas culturais de comportamentos frutos de modelos sociais moldados em um sistema patriarcal de organização e de relações dominadoras, permitindo através deste recurso dar à obra um olhar literário contestador e inovador.
\end{abstract}

\section{Palavras-chave}

Maravilhoso; papéis sociais; real; fantasia

\begin{abstract}
This article aims to analyze the occurrence of facts that escape from the conventional empirical reality in the work A bolsa amarela, by Lygia Bojunga Nunes, from the perspective of the genre Marvelous. In the fictional text it is possible to notice the recurrence of magic elements populating the narrative environment in a natural way where animals and objects undertake the characteristic of speaking and interacting with the protagonist, mixing the real and fantasy to compose the narrative. In this perspective, a critical-interpretive reading of the implausible presence as a questioning mechanism of the social behavior models imposed on Brazilian society, especially women, will be proposed for this analysis. In this work Lygia addresses the
\end{abstract}


internal and external conflicts of the character through secret friends, anthropomorphized animals and magical objects to question pre-established or stereotyped social roles, becoming the supernatural element in the narrative a way for the author to contest cultural practices of behaviors fruits of social models sculptured in a patriarchal system of organization and dominating relations, enabling through this action to give to the work a challenging and innovative literary view.

\section{KEYWORDS}

Marvelous; social behaviors; reality; fantasy

RECEBIDO 2019-03-04; ACEITE 2019-06-30

\section{Introdução: o mágico encantamento na ficção de Lygia Bojunga}

Lygia Bojunga Nunes é uma escritora brasileira que tem contribuído imensamente com a literatura infanto-juvenil no país. Consagrada nacionalmente e internacionalmente por seus inúmeros livros que divertem e encantam o público leitor mais jovem, Lygia Bojunga é uma escritora inovadora, com livros traduzidos para vários idiomas e que prima não só pelo aspecto lúdico em suas obras, mas especialmente por colocar em seu fazer literário uma percepção de mundo crítica e libertatória para seu público leitor.

Em sua vasta produção literária Bojunga nos surpreende com obras que se caracterizam por apresentar dentro do universo infanto-juvenil um simbolismo mágico que reflete sobre os relacionamentos pessoais, aborda discussões de gênero, estabelece críticas a comportamentos sociais estereotipados, sem deixar que a fantasia e o humor sejam os focos principais de sua escrita literária. Sua obra opta por uma percepção mágica dos acontecimentos sem desfazer-se do senso crítico questionador, aguçando no leitor maior autonomia para desenvolver uma leitura reflexiva que leve à mudança de paradigmas e à construção de novos discursos e formas de agir.

A delicadeza e simplicidade com que aborda os temas fazem com que as obras de Bojunga dialoguem facilmente com o imaginário infantil, pois suas narrativas estão repletas de fantasia, humor, encantamento e ludicidade, características que agradam e favorecem de forma prazerosa o desenvolvimento psíquico da criança. Considerando-se que na obra $A$ bolsa amarela Lygia Bojunga apresenta situações que transitam entre o real e o irreal, o presente estudo visa em sua análise compreender como a autora conduz os acontecimentos extraordinários na narrativa para serem portadores de reflexões e novos olhares para o leitor, a partir de situações corriqueiras e cotidianas. A presença do componente sobrenatural na trama é uma ferramenta para despertar de forma lúdica na criança uma reação de desmascaramento da realidade, de modo que ela possa perceber as múltiplas facetas do mundo contemporâneo e assumir um posicionamento diante dos fatos.

Embora Lygia Bojunga apresente uma narrativa que transcenda os limites do real, pois apresenta fatos que escapam à ordem racional e à esfera humana, esses eventos extraordinários, no entanto, não causam estranheza ou espanto para o leitor ou à personagem, adquirindo uma aparente "normalidade" dentro do eixo narrativo. Desta forma, o procedimento utilizado pela escritora 
para fazer o deslocamento da realidade convencional para uma realidade mágica permite abordar a obra dentro da esfera do relato maravilhoso. Essa perspectiva de análise se faz compreensível a partir de teorias críticas assumidas perante a presença do elemento sobrenatural na trama, que apresentam direcionamentos que levam em consideração a forma como se realiza o evento extraordinário na trama ficcional.

Lygia Bojunga é uma autora comprometida com as questões do seu tempo, tematizando de forma simbólica em seus enredos situações que envolvem uma crítica social e política da época em que a obra foi escrita, neste caso 1976, período em que o Brasil passava por uma ditadura militar no cenário político, com forte controle censor e repressor, e apresentava uma sociedade moldada em padrões fortemente patriarcais. Sob uma visão artística, através do relato maravilhoso, a autora faz ecoar em sua narrativa a apreensão de diferentes visões de mundo que se distanciam ou se contrapõem ao cenário opressor da época, a partir de uma idealização de uma sociedade de referências mais igualitárias e menos estereotipadas e impositivas.

A literatura como representação de mundo, mediada pela sensibilidade artística do escritor, é portadora dos anseios que circulam na sociedade à época da produção da obra. E de forma magistral Lygia Bojunga leva estas reflexões para o universo infantil, abordando de forma sensível, natural e lúdica para a criança, questões complexas de desigualdade de gênero, dos papéis atribuídos à mulher em uma sociedade patriarcal e conservadora, característica esta ainda bastante visível na década de 70 . Neste sentido, A bolsa amarela se constitui em uma fonte de reflexões sobre os paradigmas e valores apresentados na obra, levando-se em consideração o contexto da realidade histórica em que se inserem. Como tal, temos sob a ótica de uma personagem infantil feminina vários questionamentos, destacando-se a submissão feminina e o anseio pela ruptura de paradigmas rígidos e opressores.

A protagonista busca por inovações e mudanças na forma de pensar a sociedade e a condição feminina na década de 70, época em que os movimentos de ideais feministas buscavam desmitificar os papéis atribuídos à mulher, bem como abolir preconceitos e discriminações geradas, especialmente, por motivos sexistas. Convém realçar que de forma hábil estes temas vão sendo introduzidos e contextualizados a partir dos conflitos pessoais da protagonista infantil, os quais são decorrentes das relações familiares e sociais que presencia e vive. Ao mesclar a fantasia ao cotidiano da criança, Bojunga faz com que ela não perca seu vínculo com alguns aspectos da realidade, e, ao mesmo tempo, não deixe de fantasiar, pois "a fantasia preenche as enormes lacunas na compreensão de uma criança que são devidas à imaturidade de seu pensamento e à sua falta de informação pertinente" (Bettelheim 2002: 77).

A fantasia é o elemento essencial para mediar o mundo interno da criança com a realidade que a cerca. Assim sendo, Bojunga deixa fluir em suas narrativas a realidade pontuada por um mundo maravilhoso, que transporta a criança para um espaço simbólico onde ela constrói seus significados sem, contudo, perder a conexão com a realidade, fato que favorece seu amadurecimento e o enriquecimento de suas experiências pessoais. 


\section{Narrativas entre a realidade e a fantasia: o sobrenatural e o mágico na ficção e sua tênue divisão}

Narrativas que transcendem os limites entre o real e o imaginário sempre exerceram grande fascínio nos leitores, conquistando tanto crianças como adultos, sendo comuns na tradição literária há bastante tempo. Desde o advento das narrativas de tradição oral, o relato fantástico em suas diferentes dimensões propicia possibilidades inesgotáveis do ouvinte/leitor interagir com o sobrenatural, concebendo o mundo existente destituindo-o da realidade empírica documental e testemunhal. O evento fantástico seria nessas ficções uma realidade que não se explica pelas leis naturais, pois se contrapõe a um mundo ordenado pela lógica existencial do senso comum e do compreensível pela razão.

Para as narrativas que abordam o sobrenatural em sua temática, Todorov (2004) estabeleceu três categorias vizinhas, por ele consideradas como gêneros, cujas fronteiras são tênues e as definições ainda necessitam de maior precisão: o Fantástico, o Estranho e o Maravilhoso. Segundo ainda a teoria elaborada por Todorov, estes três gêneros ainda se subdividiriam em outros subgêneros menores. Para as narrativas fantásticas Todorov (2004: 31) discorre que "há um fenômeno estranho que se pode explicar de duas maneiras, por meio de causas de tipo natural e sobrenatural. A possibilidade de se hesitar entre os dois tipos criou o efeito fantástico”. Assim, a condição primordial para o fantástico existir, segundo Todorov, é que haja hesitação (a qual pode ser experienciada pelo leitor ou pela personagem) se aqueles acontecimentos sobrenaturais de fato existiram ou se são frutos de uma alucinação, sonho ou loucura. Outra condição ressaltada por Todorov para o fantástico existir é que a leitura das manifestações sobrenaturais fuja da interpretação poética ou alegórica.

Quanto aos gêneros Estranho e Maravilhoso Todorov esclarece que ao ver-se diante da hesitação dos fatos, o leitor ou a personagem podem tomar dois caminhos distintos, saindo do Fantástico:

Se ele decide que as leis da realidade permanecem intactas e permitem explicar os fenômenos descritos, dizemos que a obra se liga a um outro gênero: o estranho. Se, ao contrário, decide que se devem admitir novas leis da natureza, pelas quais o fenômeno pode ser explicado, entramos no gênero do maravilhoso. (Todorov 2004: 48)

No relato Estranho, os acontecimentos sobrenaturais, a alteração da ordem por um acontecimento misterioso e extraordinário, têm em seu final uma explicação racional que permite solucionar o mistério. No relato Maravilhoso, o leitor ou a personagem faz um pacto de aceitação com o sobrenatural, considerando os fatos narrados como naturais, portanto, não causam dúvida, estranheza ou medo. Para Todorov (2004: 60) o Maravilhoso é uma narrativa cujos "elementos sobrenaturais não provocam qualquer reação particular nem nas personagens, nem no leitor implícito". Os contos de fada são um exemplo de relato maravilhoso, conforme especifica Selma Calasans Rodrigues (1988: 56):

[...] o maravilhoso é um mundo do faz-de-conta: "Era uma vez", e eis-nos mergulhados em um mundo irreal. É a ficção mais radical. Fazendo uso de uma terminologia mais literária, pode-se dizer 
que, no conto de fadas, temos transposto para artifício ficcional um sistema animista de crenças, ou seja, as coisas têm alma, as plantas falam, bichos como coelhos participam da vida de uma menina ou unicórnios fazem acordos (cf. Alice no país das maravilhas, de Lewis Carroll).

Sobre o conto de fadas Todorov lembra que é comum associá-lo ao gênero maravilhoso, mas que aquele é apenas uma das categorias do maravilhoso, existindo outras variedades:

[...] o conto de fadas não é senão uma das variedades do maravilhoso e os acontecimentos sobrenaturais aí não provocam qualquer surpresa: nem o sono de cem anos, nem o lobo que fala, nem os dons mágicos das fadas (para citar apenas alguns elementos dos contos de Perrault). (Todorov 2004: 60)

Para Nelly Novaes Coelho (1987) é importante diferenciar o conto de fadas do conto maravilhoso, haja vista que estas duas formas de narrativas maravilhosas costumam ser confundidas como formas iguais, embora suas raízes sejam provenientes de fontes distintas. Os contos de fada são de "[...] origem celta e surgiram como poemas que revelavam amores estranhos, fatais, eternos" (Coelho 1987: 13). Nos contos de fadas a realização do herói se faz geralmente pela união homem-mulher e não é necessária obrigatoriamente a presença de fadas na narrativa. A respeito do argumento dos contos de fadas, Coelho explica:

[...] seus argumentos desenvolvem-se dentro da magia feérica (reis, rainhas, príncipes, princesas, fadas, gênios, bruxas, gigantes, anões, objetos mágicos, metamorfoses, tempo e espaço fora da realidade conhecida, etc.) e têm como eixo gerador uma problemática existencial. (Coelho 1987: 13)

Já os contos maravilhosos são de origem oriental e não possuem a presença de fadas, sendo um dos exemplos mais conhecidos as narrativas maravilhosas de As mil e uma noites. Nas raízes de sua origem, a autorrealização do herói não está necessariamente ligada a uma união homem-mulher como no primeiro caso, mas, geralmente, associada a uma conquista de bens materiais, poder econômico, riquezas. Segundo a citada autora:

São narrativas que, sem a presença de fadas, via de regra se desenvolvem no cotidiano mágico (animais falantes, tempo e espaço reconhecíveis ou familiares, objetos mágicos, gênios, duendes, etc.) e têm como eixo gerador uma problemática social (ou ligada à vida prática, concreta). (Coelho 1987: 14)

Em ambos os casos, o maravilhoso apresenta um grau de afastamento com a realidade, com a normalidade da natureza e dos fatos e não possui explicação racional para tais acontecimentos como no relato estranho e tampouco produz dúvida e hesitação quanto à sua veracidade como no relato fantástico. Vejamos como explica Chiampi:

Assim, enquanto na narrativa realista, a causalidade é explícita (isto é: há continuidade entre causa e efeito) e na fantástica ela é questionada (comparece pela falsidade das hipóteses explicativas), na narrativa maravilhosa, ela é ausente: tudo pode acontecer, sem que se justifique ou se remeta aos realia. (Chiampi 1980: 60) 
Nas narrativas maravilhosas a realidade ou dados da realidade são alterados, subvertendose a normalidade, porém tornando esta subversão como natural, crível e aceitável, produzindo o efeito de encantamento no leitor através do simbolismo implícito que elas contêm, pois como afirma Chiampi (1980: 48) "maravilhoso é o que contém a maravilha, do latim mirabilia, ou seja, 'coisas admiráveis' (belas, execráveis, boas ou horríveis), contrapostas às naturalia”.

A criação literária quando engloba o sobrenatural ainda carece de mais estudos críticos que possam ampliar as reflexões teóricas sobre a diversidade das narrativas metaempíricas, uma vez que acontecimentos inverossímeis ou sobrenaturais na ficção admitem diferentes flutuações que se atualizam no fantástico e em seus gêneros contíguos, pois a literatura se desenvolve e dialoga com a essência do seu tempo, propondo novas ordens de percepção estética do mundo e dos fatos que o regem.

\section{A relevância das narrativas maravilhosas para o desenvolvimento psíquico da criança}

A Psicologia tem se interessado bastante pelo estudo do desenvolvimento psíquico da criança, o qual não deixa de estar relacionado com as diversas etapas de seu desenvolvimento orgânico. Aliada à Pedagogia, estudos são feitos com o objetivo de descobrir mais sobre os gostos da criança por determinadas obras literárias, muitas delas não originalmente destinadas à infância, como os contos populares maravilhosos provenientes do folclore europeu, repleto de seres imaginários e fantásticos, mas que a atraem por responderem a determinadas características do intelecto infantil. Os estudos atuais apontam para a importância da fantasia no processo de desenvolvimento da criança, demonstrando que até os limites da puberdade a criança apresenta particularidades em relação ao seu desenvolvimento mental e à compreensão que elabora do mundo que a diferenciam da lógica racional do adulto. Neste sentido, a magia, a fantasia e o inverossímil que as narrativas metaempíricas trazem consigo dialogam intimamente com o processo psíquico da criança que está em fase de organização e estruturação e cuja realidade externa ainda carece de limites e definições. O pedagogo francês Cousinet (apud Sosa 1985: 35) fez relevantes estudos sobre as percepções de mundo para uma criança, este afirma que:

O mundo em que vivemos não é o mesmo que ela conhece. Os objetos não são os mesmos, mas algo deles próprios e de outra coisa. A boneca é uma boneca, mas também uma menina pequeninha, a cadeira é cadeira, mas também uma carruagem, um vagão de trem e um navio; a bengala é uma bengala, também um cavalo, o próprio corpo de um corpo humano e também o de um animal.

Assim, não existe uma linha clara e definidora que separe e limite a ação real da ação propiciada pela imaginação da criança a estes objetos e animais, que passam a ter uma existência similar à nossa, ou ao menos distinta do racionalismo adulto. Segundo Richard Bamberger (2006), o estímulo à leitura deve levar em consideração os interesses do leitor, que na criança vai se ajustar ao desenvolvimento de sua estrutura intelectual, evidenciando que há "idades de leitura" psicológicas. Bamberger (2006), resume, de forma objetiva e concisa, uma caracterização das fases de leitura. Assim, ele aponta que nas fases iniciais do desenvolvimento da criança, a fantasia alimenta 
seu imaginário em maior ou menor grau, de acordo com as etapas de seu desenvolvimento psíquico. Segundo alguns dos aportes teóricos citados por Bamberger (2006), na fase de 2 a 6 anos, por exemplo, "a criança faz pouca distinção entre o mundo interior e o exterior; só experimenta o meio em que vive em relação a si mesma (idade do pensamento mágico)” (Bamberger 2006: 33). $\mathrm{Na}$ fase que vai de 5 a 8 ou 9 anos, continua persistindo seu interesse pelo mundo mágico: "nesta fase do seu desenvolvimento a criança é essencialmente suscetível à fantasia" (Bamberger 2006: 34), idade que será considerada, de acordo com seu gosto de leitura, como "Idade do conto de fadas". Vejamos mais algumas considerações sobre esta fase:

No começo desse período a criança gosta principalmente de contos de fadas que representam um ambiente que lhe é familiar. Quanto menos se identifica com as personagens dos contos de fada e mais as aprecia como brincadeiras da imaginação, mais ela irá preferir personagens e histórias de um mundo distante de maravilhas. (Bamberger 2006: 34)

É neste sentido que as narrativas que lidam com o inverossímil exercem grande fascínio nas crianças: por serem uma fonte potencializadora de emoções e de ativação da fantasia no imaginário infantil, dadas as características inerentes à elaboração psíquica que as crianças apresentam em suas etapas iniciais de desenvolvimento. Segundo ainda Bettelheim (2002: 59) "o conto de fadas procede de uma maneira consoante ao caminho pelo qual uma criança pensa e experimenta o mundo; por esta razão os contos de fadas são tão convincentes para ela". À medida que sua elaboração psíquica evolui, a literatura a ela destinada também vai se adequando à sua organização mental e suas novas exigências.

Para Sosa (1985), a ficção que interessa à criança é aquela que alimenta a sua imaginação. Sua identificação expressiva com o que lhe está sendo apresentado para leitura não se dará de acordo com os gostos estéticos do adulto, mas consoante com "o caráter imaginoso que possuam, em maior ou menor grau, traduzido em mitos, ou aparições da Antiguidade, ou nos monstros, ou realidades dos tempos modernos [...]" (Sosa 1985: 36-37). O inverossímil das narrativas maravilhosas permite a aproximação do mundo interno concebido pela criança com o mundo real externo, com interações e trocas simbólicas significativas para a mesma. O processo dialógico que daí se processa poderá ajudá-la a esclarecer suas angústias, conflitos e dúvidas, estimulando-a a um encontro consigo mesma e a possíveis caminhos e soluções para os problemas levantados mediante uma linguagem metafórica ao alcance da sua compreensão.

As narrativas maravilhosas, com suas particularidades literárias singulares, descortinam a possibilidade de tratar, de forma lúdica, prazerosa e mágica para a criança, temas muitas vezes complexos, abstratos e dolorosos, como a morte, a solidão, o abandono, a fome, a carência, a opressão e outros temas existenciais, ajudando-a a lidar mais facilmente com suas próprias emoções e a compreender melhor o mundo a partir das reflexões que a leitura lhe suscita. Isso porque, como já foi dito, sob muitos aspectos, as narrativas maravilhosas atuam positivamente como espaço simbólico de intermediação entre a psique infantil e o ambiente social em que a criança vive, podendo ser um poderoso instrumento de crescimento emocional, intelectual e espiritual ao lhe proporcionar experiências que transcendem sua existência. Além disso, do ponto de vista literário, o fato das narrativas maravilhosas estimularem a imaginação não as privam de seu papel crítico em favorecer o repensar e o questionamento de papéis sociais 
estereotipados e de relações normatizadoras constituídas histórico e culturalmente dentro da sociedade.

\section{A bolsa amarela: um maravilhoso que encanta e produz reflexões}

A trama de A bolsa amarela gira em torno de Raquel, uma garotinha que possui três vontades que ela tenta reprimir sem sucesso: a vontade de crescer, a vontade de ter nascido menino, e, a que é considerada a maior de suas vontades: escrever. A narração se faz em primeira pessoa e boa parte dos diálogos mantidos na obra se constrói a partir da imaginação de Raquel. O texto inicia-se relatando essas três vontades, detendo-se naquela que começou a ganhar mais força - a vontade de escrever. A partir desta vontade, Raquel começa a escrever cartas para amigos imaginários como o André e a Lorelai. Já nas primeiras páginas, o encantamento se instala, pois Bojunga parte da imaginação infantil de Raquel para transbordar a realidade de eventos aparentemente inverossímeis. A realidade deixa de ser racional e passa a adquirir uma instância mágica, maravilhosa. O insólito se mescla à realidade quando estes amigos "imaginários" de Raquel começam a responder suas cartas, que surgem das mais diversas formas para a protagonista. A realidade concreta se transmuta em simbólica, e a percepção do mundo se enche de magia:

Esperei a resposta uma porção de dias. Até que uma tarde deu uma ventania danada. A janela do quarto estava aberta, entrou folha de árvore, poeira, e um papel todo escrito com a letra do André. Vibrei: era uma carta no duro, maior até do que as minhas (Bojunga 2000: 15)

Apesar de Raquel mencionar a princípio que seus amigos são inventados, a forma como a narrativa é elaborada estabelece um jogo de sedução do narrador para com o leitor, dando margem para que o leitor se sinta sugestionado a pensar que de fato Raquel realmente está recebendo cartas, que aparecem de forma misteriosa: "No dia seguinte, quando entrei no elevador, encontrei um papel caído no chão. Era um bilhete da Lorelai” (Bojunga 2000: 19). Raquel havia criado amigos imaginários, entretanto, estes amigos imaginários parecem tomar vida própria, passando a responder às cartas da protagonista e fazendo-a ansiar por suas respostas. Instala-se desde o início da trama o teor maravilhoso da narrativa, ou seja, fatos que embora não pertencentes ao mundo natural dos acontecimentos, não causam medo, surpresa ou estranheza, pois são vistos como fatos críveis e aceitáveis por parte da protagonista. Esta abordagem produz um efeito de encantamento no leitor que passa a aceitar sem surpresa o irreal como parte da narrativa, num pacto de aceitação mútua entre narrador e leitor.

O elemento maravilhoso, que começa a ser construído na narrativa logo nas primeiras páginas, projeta no imaginário infantil a realidade mesclada à fantasia. A estratégia elaborada por Bojunga faz com que a fantasia não seja vista como uma ruptura com a realidade, mas como parte dela, o que para criança adquire coerência interna, pois ela vivencia a realidade permeada por fantasias, como explica Bettelheim:

Uma criança defrontada com problemas e situações cotidianas de perplexidade é estimulada, no seu aprendizado, a compreender o "como" e o "por que" de tais situações, e a buscar 
soluções. Mas como sua racionalidade até então exerce pouco controle sobre o inconsciente, a imaginação escapa, junto com ele, sob a pressão de suas emoções e conflitos não resolvidos. (Bettelheim 2002: 78)

O maravilhoso que se instaura na narrativa começa a se processar a partir das fantasias, sonhos e devaneios de Raquel, como a criação de amigos imaginários. A fantasia criada por Raquel é um elemento que vai suscitando no interior da protagonista uma caminhada de descobertas e questionamentos profundos, e para os quais ela busca encontrar soluções, como no caso das relações familiares deterioradas e que ela deseja de alguma forma não ser afetada emocionalmente por tais situações, fato que ela narra em uma de suas cartas a Lorelai:

Meu pai e minha mãe viviam rindo, andavam de mão dada, era uma coisa muito legal da gente ver. Agora tá tudo diferente: eles vivem de cara fechada, brigam à toa, discutem por qualquer coisa. $\mathrm{E}$ depois, toca todo mundo a ficar emburrado. [...] Eu queria tanto achar um jeito de não dar mais bola para briga e pra cara amarrada. Será que você não acha um jeito para mim? (Bojunga 2000: 18)

Raquel narra suas angústias para seus amigos imaginários e estes passam a respondê-la através de cartas que vão surgindo da maneira mais inesperada possível. Tudo isso se processará como fruto do imaginário de uma menina cujas fantasias e amigos irreais são importantes no seu processo de amadurecimento. Nestas cartas, além de expor seus conflitos interiores de criança, como o fato de ser incompreendida por seus familiares, suas vontades reprimidas e que ela não sabe o que fazer com elas, há a constatação de um mundo cujos valores patriarcais e relações autoritárias são bastante fortes. Diante das situações que a pequena protagonista se vê envolvida, inicia-se um processo gradativo de autoconhecimento e transformações, numa jornada interior que a levará ao crescimento como pessoa e à reafirmação de sua identidade.

Ressalte-se que o inverossímil produzido na narrativa tem uma função intencional de levar a uma construção identitária da personagem Raquel. Este maravilhoso se desdobrará em novas facetas, pois além dos amigos imaginários das cartas, surgirão como parte do enredo animais falantes, como o galo Afonso e o galo Terrível, além de objetos que ganham vida e animação, desejos e vontades próprias, como o guarda-chuva e o alfinete de fraldas. Todos guardados em segredo dentro da bolsa amarela. Esta bolsa representa uma existência mais simbólica que física para a narrativa, pois é o espaço que abre possibilidade para descobertas e revelações, frutos da compreensão de si mesmo, das percepções sobre o outro, sobre o mundo e sobre as concepções ideológicas que dinamizam as relações sociais.

O surgimento da bolsa amarela na vida da pequena protagonista se dá a partir da narração de um evento costumeiro na família de Raquel: as doações da "tia Brunilda”. Um certo dia, a família de Raquel recebe um pacote com doações de roupas, sapatos e outros utensílios da tia Brunilda. Deste pacote, após todos da casa escolherem o que queriam, sobra uma bolsa amarela que ninguém quer. Esta bolsa acaba ficando com Raquel, que a elege como o esconderijo perfeito para suas coisas: retratos, os nomes que ela vinha guardando, um alfinete de fralda, desenhos feitos por ela, e, dentre outras coisas, Raquel resolve guardar, ou melhor, "prender" na bolsa suas vontades reprimidas: 
Abri um zipe; escondi fundo minha vontade de crescer; fechei. Abri outro zipe; escondi mais fundo minha vontade de escrever; fechei. No outro bolso de botão espremi a vontade de ter nascido garoto (ela andava muito grande, foi um custo pro botão fechar). Pronto! A arrumação tinha ficado legal. Minhas vontades tavam presas na bolsa amarela, ninguém mais ia ver a cara delas. (Bojunga 2000: 30)

Neste aspecto, a bolsa amarela, além de servir de refúgio protetor para suas vontades, funcionará como um espaço simbólico de libertação e desconstrução de estereótipos dentro do ambiente social vivido por Raquel. De dentro da bolsa amarela vão surgindo personagens significativos que darão o contraste com a realidade já existente e conhecida pela protagonista e com a qual ela não concorda ou questiona. O galo Afonso é um desses personagens emblemáticos e simbólicos que surge, de forma inexplicável, de dentro da bolsa amarela e conversando naturalmente, como se fosse humano, com a pequena protagonista:

Acordei de repente com um barulho esquisito. Olhei pra janela e vi o dia nascendo. Outra vez o barulho. Quase morro de susto: era um canto de galo; e ali bem perto de mim. [...] Mas aí o galo cantou muito aflito: um canto assim de gente que tá presa e quer sair. “Tá dentro da bolsa amarela!" Abri a bolsa correndo. O galo saiu lá de dentro.

- Puxa, se você não abre essa bolsa eu morria sufocado. Tinha pedido pro fecho ficar meio aberto pra eu poder respirar, mas ele acabou dormindo e fechou. (Bojunga 2000: 33)

Vale ressaltar que o galo Afonso é um personagem que representa uma visão bastante inovadora para a época. O galo Afonso é uma figura que questiona a dependência feminina e a desigualdade dos sexos. Problematiza, em especial, a condição de submissão e docilidade que era exigida das mulheres na época de escritura do romance, na década de setenta. Em suma, o personagem ao assumir posturas críticas opostas a padrões culturais que valorizavam a superioridade masculina, propicia ao leitor ampliar suas percepções, estimulando reflexões capazes de levar a um processo de desconstrução de estereótipos. Na narrativa, o galo Afonso é o oposto do que se esperava de um galo, pois Afonso vivia em um galinheiro com quinze galinhas, mas não gostava de ser o "chefe" delas, pois tinha idéias revolucionárias de igualdade de direitos entre homens e mulheres e era contra relações dominadoras em que um tem que mandar e o outro obedecer. Analisemos os fragmentos a seguir:

Então eu chamei minhas quinze galinhas e pedi, por favor, pra elas me ajudarem. Expliquei que vivia muito cansado de ter que mandar e desmandar nelas todas as noite e dia. Mas elas falaram. "Você é nosso dono. Você é que resolve tudo pra gente". Sabe, Raquel, elas não botavam um ovo, não davam uma ciscadinha, não faziam coisa nenhuma, sem vir perguntar: "Eu posso? Você deixa?" E eu respondia: “Ora, minha filha, o ovo é seu, a vida é sua, resolve você como você achar melhor", elas desatavam a chorar, não queriam mais comer, emagreciam, até morriam. Elas achavam que era melhor ter um dono mandando o dia inteiro: faz isso! faz aquilo! Bota um ovo! Pega uma minhoca! do que ter que resolver qualquer coisa. Diziam que pensar dá muito trabalho. (Bojunga 2000: 35)

[...] 
— Fiquei danado. Subi no puleiro e berrei: "Não quero mandar sozinho! Quero um galinheiro com mais galos! Quero as galinhas mandando junto com os galos!” (Bojunga 2000: 36)

Essas reflexões são colocadas de uma maneira lúdica, leve e bem-humorada para o leitor infantil, através de um personagem animal antropomorfizado, que favorece uma interação imediata com as crianças, haja vista que os animais por sua própria natureza são capazes de estabelecer uma relação de empatia instantânea com as mesmas. Seguindo esta percepção Bojunga reforça sua crítica social na narrativa através de outro personagem animal: o galo Terrível, primo de Afonso, que foi condicionado a ser um galo de briga e a morrer lutando em rinhas de galos. Através deste personagem pode-se perceber uma crítica a papéis sociais estereotipados e às relações dominadoras.

Utilizando-se da fantasia de cunho maravilhoso, com animais falantes e objetos com vida própria, a narrativa de $A$ bolsa amarela está repleta de exemplos que abrem espaço para novas visões de mundo, como na passagem que segue:

Terrível pulou pro meio da roda. A briga começou.

Crista de Ferro lutava muito melhor, e achava que lutar era legal (na certa o pensamento dele também tinha sido costurado).

Terrível começou a perder. Perdeu sangue, perdeu duas penas, foi ficando cansado.

A Linha Forte cada vez fazia mais força pra dar um jeito. Quanto mais o Terrível apanhava, mais força ela fazia. Mais força. Mais força. Até que de repente - plá!!! - de tanto fazer força, rebentou. E foi só ela rebentar que o pensamento do Terrível descosturou, abriu todinho, e ele desatou a pensar mil coisas, ficou até tonto de tanto pensamento junto. Num instante entendeu tudo que estava acontecendo, e é claro que não sendo bobo pensou logo: besteira eu morrer nessa praia só porque eles cismaram que eu tenho que brigar com o Crista de Ferro. E se mandou! Correu pro mar. (Bojunga 2000: 88)

Os personagens da narrativa como o galo Afonso, o Terrível, o alfinete de fraldas, o guardachuva, as linhas de carretel, adquirem vida própria, carregam problemáticas dentro de si, têm desejos e frustrações, medos e sonhos como qualquer ser humano. São seres imaginários que buscam a felicidade e o encontro consigo mesmo e suas aspirações, assim como a pequena Raquel. O efeito maravilhoso advindo com a criação destes personagens, a magia e a fantasia que eles trazem para a narrativa, além de encantarem a criança, favorecem a tomada de consciência sobre outras realidades possíveis na sociedade, uma vez que estes personagens, muitas vezes, desestabilizam a realidade que os cercam com valores que são opostos aos já existentes, como no caso do galo Afonso que se recusou a ser o chefe que toma de conta de um galinheiro e partiu em busca do que acalentava seu coração e não do que pré-determinava os padrões sociais de comportamento em vigor. Seguindo a mesma trajetória, com mágica e encantamento, o galo Terrível liberta-se dos pensamentos a que foi condicionado e parte em busca de suas próprias ideias e sonhos. Com estes personagens a criança compartilha a possibilidade de ampliar suas percepções sobre o mundo que a cerca, sobre as relações e papéis sociais que encontra em seu meio e, a partir daí, exercer um pensamento mais crítico e consciente, capaz de contestar e propor novas configurações comportamentais para evitar padrões cristalizados na sociedade não ficcional. 
Nesta mesma perspectiva de estimular a reflexão do leitor infantil, a autora apresenta a casa dos consertos na narrativa, um espaço diferente da casa de Raquel, onde ela conhece o modo de viver da família de Lorelai, a amiga imaginária de Raquel do início da trama e que volta a surgir no final do enredo, acrescentando importantes descobertas à aprendizagem espiritual da protagonista. Neste capítulo intitulado "Comecei a pensar diferente", a casa dos consertos materializa a tomada de consciência de Raquel de que outras realidades familiares são possíveis, e outras construções sociais são reveladas, acelerando o processo de amadurecimento da protagonista. Na família de Raquel, as relações são frutos de um poder central, baseadas na ideia de um chefe familiar que comanda as ações. Na casa dos consertos, Raquel percebe que não há um chefe, todos se ajudam mutuamente a resolver os problemas e as decisões são compartilhadas por todos, inclusive as crianças, que deixam de ser indivíduos sem vontade própria, à mercê das vontades dos adultos, revalorizando a criança como ser pensante, como mostram os diálogos abaixo:

— Quem é que resolve as coisas? quem é o chefe?

- Chefe?

— É o chefe da casa. Quem é? Teu pai ou teu avô?

- Mas pra que que precisa chefe?

$[\ldots]$

— Não tem sempre uma porção de coisas para resolver? Quem é que resolve?

- Nós quatro. Pra isso todo dia tem hora de resolver coisa. Que nem ainda há pouco teve hora de brincar. A gente senta aí na mesa e resolve tudo que precisa. Resolve como é que vai enfrentar um caso que a vizinha criou; resolve se vai brincar mais do que trabalhar; ou estudar mais do que brincar; resolve o que é que vai comer; quanto é que vai gastar em roupa, em comida, em livro; resolve essas transas todas. Cada um dá uma ideia. E fica resolvido o que a maioria achar melhor. (Bojunga 2000: 99-100)

Neste processo de descobertas, a narrativa retoma a problemática de Raquel de querer ser menino por achar que o mundo privilegiava o sexo masculino em detrimento do feminino. Ao perguntar quem era o chefe da casa, Raquel só oferece a Lorelai opções masculinas: “Teu pai ou teu avô?", o que cristaliza na menina a concepção negativa de que ser mulher é estar numa situação secundária, possivelmente de submissão. Ao perceber que as coisas podiam ser diferentes, os estereótipos negativos cedem a novas visões de mundo, a novos valores. É desta forma que a vontade de ser menino e ser adulto vai desaparecendo e Raquel vai reavaliando que ser mulher e ser criança (em uma única palavra - ser menina) podia ser bastante gratificante, o que fortalece a sua identidade feminina:

Comecei a achar então que ser menina podia mesmo ser tão legal quanto ser garoto. E foi aí que minhas vontades deram para emagrecer. Emagreceram, emagreceram, até que um dia pensei: daqui a pouco elas vão sumir. (Bojunga 2000: 109)

Bojunga através da presença de elementos típicos das narrativas maravilhosas, como animais falantes, amigos imaginários que adquirem existência própria e objetos que possuem uma esfera mágica e simbólica, vai abordando temas complexos e criando espaços de reflexão para o leitor 
infantil através de situações que dialogam diretamente com seu imaginário por meio da fantasia. Desta forma, a escritora instaura na narrativa possibilidades diversas para que o leitor se reconheça como autor de sua própria história, criador e transformador de suas experiências, de um mundo que não é fixo e imutável, e cujos papéis sociais podem ser resignificados de acordo com as necessidades de cada indivíduo, apresentando uma mensagem positiva de que é possível despertar para novas realidades e fazê-las acontecerem.

\section{Considerações finais}

Lygia Bojunga reveste A bolsa amarela de um maravilhoso que interage diretamente com a psique infantil. A temática de uma menina cheia de conflitos identitários é abordada nesta obra de maneira simples para a criança, com personagens que fazem parte do seu universo infantil onde a fantasia se mescla à realidade sem grandes conflitos e de maneira prazerosa para o jovem leitor.

$\mathrm{O}$ enredo que mescla fantasia à realidade seduz o leitor e o convida a entrar neste jogo de faz de contas, produzindo um efeito de sentidos que leva à tomada de consciência e à percepção crítica enquanto vão sendo narradas as peripécias da protagonista com seus amigos imaginários.

Neste sentido, a entrada do efeito maravilhoso na obra de uma escritora contemporânea como Bojunga se configura como um dispositivo de questionamento de papéis sociais, imagens e preconceitos estereotipados em função do sexo, da relação adulto-criança e de relações dominadoras frutos de um sistema de crenças patriarcais, e até mesmo do contexto político e social que vivia o país na época da publicação da obra.

A bolsa amarela é o espaço simbólico onde todos estes conflitos vão surgir e suscitar reflexões na protagonista em sua jornada espiritual em busca do crescimento e do encontro consigo mesma, com suas emoções e com as formas de lidar com o mundo. Concepções que ela vai desconstruindo ou reelaborando, de acordo com a compreensão que ela vai alcançando da realidade externa que a cerca, sendo a sua imaginação a ponte que conectará sua realidade interna com o mundo exterior. Raquel, a protagonista da história, irá aprender através da fantasia e do inverossímil como lidar com seus próprios conflitos e crescer como pessoa, em busca da felicidade. A bolsa amarela, que no início da narrativa é fuga simbólica para os problemas, passa a ser ao final da jornada de Raquel a referência simbólica de sua liberdade criadora rumo à sua independência e autoafirmação.

Nesta perspectiva, os fatos maravilhosos apresentados no enredo da obra funcionam como parte de um mecanismo que contribui para instigar, de forma lúdica e prazerosa, um aprendizado e amadurecimento crítico no jovem leitor infantil. Através de uma trama repleta de acontecimentos impossíveis pela ótica do racional é que vão se realizando apropriações simbólicas significativas para novas percepções e mudanças de paradigmas, em que o elemento maravilhoso, sobrenatural na trama, levará o leitor a novas possibilidades de compreensão de si mesmo, dos outros e do mundo que o cerca. 


\section{Referências bibliográficas}

Bamberger, R. (2006). Como incentivar o hábito de leitura. $7^{\text {a }}$ ed. Trad. O. Mendes Cajado. São Paulo: Ática/ Unesco.

Bettelheim, B. (2002). A psicanálise do conto de fadas. Trad. A. Caetano. Rio de Janeiro: Paz e Terra.

Bojunga, L. (2000). A bolsa amarela. Rio de Janeiro: Agir.

Chiampi, I. (1980). O Realismo Maravilhoso. São Paulo: Perspectiva.

Coelho, N. N. (1987) O conto de fadas. São Paulo: Ática.

Rodrigues, S. C. (1988). O fantástico. São Paulo: Ática.

Sosa, J. (1985). A literatura infantil. São Paulo: Cultrix.

Todorov, T. (2004). Introdução à literatura fantástica. $3^{\text {a }}$ ed. Trad. M. C. Correa Castello. São Paulo: Perspectiva. 